\title{
Performance of eventing horses fed high fat diet ${ }^{1}$
}

\author{
Fernanda Nascimento de Godoi ${ }^{2}$, Fernando Queiroz de Almeida ${ }^{3}$, Eduardo Xavier Ferreira \\ Migon $^{4}$, Hélio Fernando Moura de Almeida ${ }^{4}$, Ana Beatriz Fonseca Monteiro ${ }^{5}$, Tiago Marques \\ dos Santos 6
}

\footnotetext{
${ }^{1}$ Pesquisa financiada pelo CNPq/FAPERJ/EsEqEX.

2 Programa de Pós-graduação em Zootecnia - UFRRJ. Bolsista da CAPES.

3 Instituto de Veterinária - UFRRJ. Bolsista Pesquisador CNPq.

${ }^{4}$ Escola de Equitação do Exército - EsEqEx. Especialista em Equitação.

${ }^{5}$ Departamento de Estatística, UFF. Bolsista Pesquisador CNPq.

6 Instituto de Veterinária - UFRRJ. Bolsista da CAPES.
}

ABSTRACT - The objective of this study was to the evaluate physiological, hematological and biochemical parameters of eventing horses fed diets containing soybean oil and submitted to physical effort tests. Twelve horses were used in a completely randomized design with two diets and six replications. The diets used were: diet without soybean oil inclusion (control) and diet with inclusion of $10 \%$ soybean oil. The experiment lasted 82 days, with three exercise tests: at the beginning, $60^{\text {th }}$ and $82^{\text {th }}$ day of the experiment. There were five data collections for each test: before the test with the horses at rest immediately after the test, and at 10,20 and 120 minutes after each test. Body temperature and rate heart were taken and blood samples were collected to evaluate hematological and biochemical variables. The mean values of the physiological, metalogical and biochemical parameters were submitted to non-parametric analysis. The inclusion of soybean oil only altered the $\gamma$-glutamyltransferase (GGT) and creatinine concentration in function time of intake of the diet. There was effect of trainings time on the horses conditioning that improved with reduction in the lactate concentration while the glucose concentration increased at the last exercise test.

Key Words: horses, nutrition, riding, training

\section{Desempenho de equinos de concurso completo de equitação alimentados com dieta contendo óleo de soja}

\begin{abstract}
RESUMO - Objetivou-se avaliar os parâmetros fisiológicos, hematológicos e bioquímicos de equinos de concurso completo de equitação consumindo dieta contendo óleo de soja e submetidos a testes de esforço físico. Foram utilizados 12 equinos em delineamento experimental inteiramente casualizado, com duas dietas e seis repetições. As dietas utilizadas foram: dieta sem inclusão de óleo de soja (controle); dieta com inclusão de $10 \%$ de óleo de soja. O ensaio teve duração de 82 dias e incluiu três testes de esforço físico: ao início, no $60^{\circ}$ e no $82^{2}$ dia. Em cada teste, foram realizadas cinco coletas de dados: antes do teste com os animais em repouso; imediatamente após o teste; e 10, 20 e 120 minutos após os testes. Foram avaliadas a temperatura corporal e a frequência cardíaca e realizadas coletas de amostras de sangue para análises hematológicas e bioquímicas. Os valores médios dos parâmetros fisiológicos, hematológicos e bioquímicos foram submetidos à análise não-paramétrica. Somente ao longo do tempo de consumo das dietas, a inclusão do óleo de soja somente alterou a concentração de $\gamma$-glutamil transferase (GGT) e creatinina. O tempo de treinamento físico tem efeito no condicionamento dos equinos, que melhora com a redução da concentração de lactato, e na concentração de glicose, que aumentou no teste de esforço físico.
\end{abstract}

Palavras-chave: cavalos, equitação, nutrição, treinamento

\section{Introduction}

Eventing is an Olympic equestrian sport with three tests: dressage, cross country and show jumping that takes place over three days, with the same rider-horse (FEI, 2007). The horses need a high energy concentrate in the diets (Andrews et al., 1995) and these requirements depend on the intensity and length of the exercise. Many factors influence the exercise intensity, including the speed and the type of track, whether grass or sand. There are other related factors that influence the energy requirements of eventing horses, which include the quantity and height of the obstacles, gait and the rider and equipment weight (Evans, 2000). 
Including oils and fat in athletic horses diets tends to meet the high requirements, and according to the NRC (2007), adding oils to diets increases horse performance in function of: 1) better energy/weight relation, that reduces dry matter intake and gastrointestinal tract weight; 2) lower metabolic heat produced, associated to digestion and exercise; 3 ) higher exercise endurance due to lower muscular glycogen use; 4) better performance in short distance races, due to energy increase from glycolysis; and 5) reduced $\left[\mathrm{H}^{+}\right]$levels during high intensity exercise.

Haematological variables are used in clinical-pathological evaluation of horses at training and racing, that are practical and cheap (Hodgson \& Rose, 1994). Lindner (2000) stated that the most used variables to evaluate a horse's conditioning are: heart rate, body temperature and blood lactate concentration. The latter correlates best with horse performance.

The objective of this study was to evaluate the physiological, haematological and biochemical variables of eventing horses fed diets with soybean oil and submitted to exercise tests.

\section{Material and Methods}

The experiment was carried out at the Escola de Equitação do Exército with 12 half-breed horses, with $5.3 \pm 1.4$ years old, $456 \pm 34 \mathrm{~kg}$ and body condition score varying from 4.5 to 5.0 (Henneke et al., 1983). The study was conducted in a completely randomized design with 2 treatments (diets) and 6 replications (horses). The experiment lasted 82 days, with the three exercise tests, at the beginning, the $60^{\text {th }}$ and the $82^{\text {th }}$ day. At these times, the maximum and minimal temperatures were 26.8 and $15.0^{\circ} \mathrm{C}, 24.9$ and $13.2^{\circ} \mathrm{C}$, and 31.0 and $18.5^{\circ} \mathrm{C}$ respectively, according to the Brazilian Institute of Meteorology.

The experimental diets were: diet without soybean oil, and consisting of commercial concentrate (RH Rodeio Socil), soybean meal, mineral mix, salt and coast-cross hay (Cynodon dactilon L. Pers) (control); diet with the inclusion of $10 \%$ soybean oil consisting of commercial concentrate, soybean meal, soybean oil, mineral mix, salt and coast-cross hay. The diets were formulated according mature horses' nutritional requirements, exercise and the animal's weight (NRC, 1989).

The soybean oil was included in the diet gradually for the horses' digestive tract to adapt. Four steps were used to include the soybean oil in the diet, with increasing percentages of $30,50,70$ and $100 \%$ from the estimated total daily oil intake, an average of $1100 \mathrm{~mL}$, varying according to individual diet intake. Each step took seven days, during 28 days, so that at the second exercise test all the horses were adapted to the hyperlipidemic diet.

The concentrate was gradually reduced in the diet as soybean oil was included according to diet energy increase, keep the 67:33 concentrate:roughage ratio on dry matter basis. Soybean meal was added to the diets to balance the protein contents (Table 1).

Dry matter intake was reduced $1.34 \mathrm{~kg}$ in horses fed the diet with soybean oil compared to the control diet, and the energy and protein intakes, in $\mathrm{g} / \mathrm{kg}$ bodyweight, were similar between the two diets. The soybean oil inclusion increased ether extract to $1.59 \mathrm{~g} / \mathrm{kg}$ body weight (Table 2).

During the study, the horses were trained for eventing. Daily training was 1.5 hour of intense activity, covering physical and technical conditioning to participate in events

Table 1 - Ingredients and nutritional compositions of the diets, on dry matter basis

\begin{tabular}{|c|c|c|}
\hline \multirow[t]{2}{*}{ Ingredient } & \multicolumn{2}{|c|}{ Soybean oil inclusion (\%) } \\
\hline & 0 & 10 \\
\hline Concentrate $(\%)$ & 65.4 & 44.8 \\
\hline Soybean meal (\%) & 0.8 & 11.0 \\
\hline Soybean oil (\%) & 0.0 & 9.8 \\
\hline Coast-cross hay $(\%)$ & 33.0 & 33.0 \\
\hline Salt $(\%)$ & 0.6 & 0.6 \\
\hline Mineral $\operatorname{mix}^{1}(\%)$ & 0.2 & 0.6 \\
\hline Total & 100 & 100 \\
\hline \multicolumn{3}{|l|}{ Nutritional composition } \\
\hline Dry matter $(\%)$ & 88.1 & 89.4 \\
\hline Organic matter $(\%)$ & 87.8 & 89.6 \\
\hline Crude protein $(\%)$ & 10.8 & 13.7 \\
\hline Ether extract $(\%)$ & 4.7 & 13.3 \\
\hline Neutral detergent fiber $(\%)$ & 55.6 & 47.5 \\
\hline Acid detergent fiber (\%) & 23.5 & 20.8 \\
\hline Cellulose $(\%)$ & 16.2 & 14.8 \\
\hline
\end{tabular}

Table 2 - Horse weights and daily nutrient intake in the experimental diets

\begin{tabular}{lcc}
\hline Item & Soybean oil inclusion (\%) \\
\cline { 2 - 3 } & 0 & 10 \\
\hline Body weight (kg) & 445.6 & 478.1 \\
Dry matter (kg) & 11.23 & 9.89 \\
Dry matter (\% LW $\left.{ }^{1}\right)$ & 2.42 & 1.98 \\
Crude protein (kg) & 1.21 & 1.35 \\
Crude protein (g/kg LW) & 2.73 & 2.75 \\
Gross energy (Mcal) & 45.7 & 45.7 \\
Ether extract (kg) & 0.43 & 1.26 \\
Ether extract (g/kg LW) & 0.98 & 2.57 \\
Neutral detergent fiber (kg) & 6.24 & 5.56 \\
Acid detergent fiber (kg) & 2.64 & 2.06 \\
Hemicellulose (kg) & 3.60 & 2.64 \\
\hline
\end{tabular}

${ }^{1}$ Live weight. 
at the national level, at the young horses stage. On average, the training consisted of 17 minutes at the walk, 30 minutes at the trot, 11 minutes at the canter, and the remaining time at show jumping.

Exercise training aimed to increase cardio respiratory performance by interval training which is made up of steps with different types of walk and rest intervals (Evans, 2000). To verify training intensity and the horses' exercise capacity, an exercise test was structured and carried out on a $925 \mathrm{~m}$ oval, grass clod track, according to the protocol: 17 minutes warming up at walk and trot, followed by 3 minutes at the gallop at $450 \mathrm{~m} / \mathrm{min}(7.5 \mathrm{~m} / \mathrm{s}), 3$ minutes at walk; 3 minutes at the gallop with 90 seconds at $450 \mathrm{~m} / \mathrm{min}(7.5 \mathrm{~m} / \mathrm{s})$ and 90 seconds at maximum speed. Whip and spurs should not be used. During the test, three groups were set up with four rider-horse sets, in a total of 12 sets. On test day, the horses were fed concentrate five hours prior to the beginning of tests (Almeida et al., 2003).

At each test, data were taken at five moments: before the test with the horses at rest, immediately after the test, and at 10,20 and 120 minutes after each test.

Blood samples for hematologic analysis were collected in tubes with EDTA and maintained at $4{ }^{\circ} \mathrm{C}$. Packed cell volume was determined by the microhematocrit method. Hematimetry and total leukocytes were evaluated in a Neubauer chamber, and white blood cells by blood smears stained with Panotic in an optical microscope (Coles, 1984). Total solid concentration and fibrinogen was estimated by refratrometry, and hemoglobin by spectofotrometry. Mean corpuscular volume (MCV) and mean corpuscular hemoglobin concentration (MCHC) were obtained by relating the variables described (Smith, 1993).

Blood samples for glucose and lactate analysis were collected in tubes with sodium fluoride. Blood samples for analysis of triglycerides, cholesterol, urea, creatinine, $\gamma$-glutamyltransferase (GGT), creatine kinase (CK) and aspartate aminotransferase (AST) were collected in tubes without anticoagulant. After collecting, the samples were centrifuged for $7000 \mathrm{~g}$ for 10 minutes and $1 \mathrm{~mL}$ aliquots were taken and stored at $-20{ }^{\circ} \mathrm{C}$ in polypropylene tubes until analysis. Biochemical analyses were carried out by the colorimetric enzymatic method using the Laborlab ${ }^{\circledR}$ commercial kit.

Hematologic variables, and triglycerides, cholesterol and urea nitrogen serum concentrations were evaluated from the horses at rest, before the exercise tests.

Digestible nutrient intake values were submitted to analysis of variance and compared by the Fisher test $(\mathrm{P}<0.05)$ using the Statistics and Genetics Analysis - SAEG software version 9.1 (UFV, 2000). The values of the physiological, hematologic and biochemical were submitted to non parametric analysis and compared by the Mann-Whitney, Friendman and Wilcoxon tests for differences between ordered pairs $(\mathrm{P}<0.05)$ in the Statistical Package for the Social Sciences - SPSS, version 12.0.

The Mann-Whitney test was used to evaluate the effect of including soybean oil and the Friedman test was used to evaluate exercise tests and the time of blood collection in each test. When the result was significant by the Friedman test, the Wilcoxon test for differences between ordered pairs was used to compare results from the same horse.

\section{Results and Discussion}

Horses presented an average body gain of $0.2 \mathrm{~kg} / \mathrm{day}$ during the experiment, regardless of the diet, maintaining body condition score adjusted to the equestrian competition.

During the 82 days of experiment, the horses fed a hyperlipidemic diet were healthy and there were no cases of diarrhea or colic, similar to that reported by Duren et al. (1987), with horses fed diets with the addition of $20 \%$ corn oil. Also Godoi et al. (2009a) did not observe gastrointestinal disorders or alterations in the feces in horses fed diets with the addition of $19.5 \%$ soybean oil; and Zeyner et al. (2002) did not observe any bad effects in horses fed diet with the addition of $11.5 \%$ soybean oil.

Digestible nutrients were calculated according to nutrient digestibility coefficients of a similar diet estimated by Godoi (2009b). Horses fed the $10 \%$ soybean oil diet presented lower digestible dry matter intake $(\mathrm{P}=0.004)$ with a reduction of $0.8 \mathrm{~kg} /$ day, compared to the control diet (Table 3). This showed the higher digestible energy availability of soybean oil, so that the dry matter intake could be reduced, and consequently, non-structural

Table 3 - Daily intake of digestible nutrients of horses fed experimental diets

\begin{tabular}{lcccc}
\hline Nutrient & \multicolumn{3}{c}{$\begin{array}{c}\text { Soybean oil } \\
\text { inclusion }(\%)\end{array}$} & \\
\cline { 2 - 4 } & 0 & 10 & $\mathrm{CV}(\%)$ & $\mathrm{P}$ \\
\hline Digestible dry matter $(\mathrm{kg})$ & $7.00 \mathrm{a}$ & $6.21 \mathrm{~b}$ & 3.73 & 0.004 \\
Digestible protein $(\mathrm{kg})$ & $0.85 \mathrm{~b}$ & $1.12 \mathrm{a}$ & 3.52 & 0.000 \\
Digestible protein $(\mathrm{g} / \mathrm{kg} \mathrm{LW})$ & $1.84 \mathrm{~b}$ & $2.18 \mathrm{a}$ & 0.78 & 0.000 \\
Digestible energy (Mcal) & $31.3 \mathrm{a}$ & $33.3 \mathrm{a}$ & 8.12 & $\mathrm{NS}$ \\
Digestible energy (kcal/LW) & $0.06 \mathrm{a}$ & $0.06 \mathrm{a}$ & 6.80 & $\mathrm{NS}$ \\
Digestible ether extract $(\mathrm{kg})$ & $0.31 \mathrm{~b}$ & $1.16 \mathrm{a}$ & 1.87 & 0.000 \\
Digestible ether extract $(\mathrm{g} / \mathrm{kg}$ PV) & $0.70 \mathrm{~b}$ & $2.32 \mathrm{a}$ & 1.88 & 0.000 \\
Digestible neutral detergent fiber $(\mathrm{kg})$ & $3.26 \mathrm{a}$ & $2.23 \mathrm{~b}$ & 4.57 & 0.000 \\
Digestible hemicellulose $(\mathrm{kg})$ & $2.21 \mathrm{a}$ & $1.31 \mathrm{~b}$ & 8.60 & 0.000 \\
\hline CV - coefficient of variation. & & & & \\
Values in a line, followed different letters are different $(\mathrm{P}<0.05)$ by Fisher test.
\end{tabular}


carbohydrates could be replaced by lipids that are beneficial to athlete horses, because it reduces the digestive tract weight and risks of diarrhea and colic and thus can improve their performance.

The digestible protein intake by horses fed with soybean oil in the diet was higher $(\mathrm{P}=0.004)$, with an average daily value of $1.12 \mathrm{~kg}$. The inclusion of soybean meal to adjust the diet increased the digestible protein content, because soybean meal protein presents high digestibility, of $94.8 \%$, cited by Almeida et al. (1998), or $92.2 \%$ cited by NRC(2007).

The digestible energy (DE) intake did not differ $(\mathrm{P}>0.05)$ between the two diets, on average of $31.8 \mathrm{Mcal} /$ day and $0.06 \mathrm{kcal} / \mathrm{LW}$, because added soybean oil, with $8.98 \mathrm{Mcal}$ DE/kg DM (Frape, 2004), substituted energy in the concentrate, showing that the diets were balanced for similar digestible energy content.

There was effect on the soybean oil inclusion, increasingly significant digestible ether extract intake, of $1.53 \mathrm{~g} / \mathrm{kg} \mathrm{BW}$, because soybean oil contains $99.6 \%$ ether extract and $95 \%$ digestibility (Kronfeld et al., 2004). On the other hand, there was a meaningful reduction in the fiber intake in horses fed the hyperlipidemic diet, because there was less hay available to maintain the concentrate:roughage ratio constant. Digestible neutral detergent fiber and digestible hemicellulose intake reduced 1.03 and $0.9 \mathrm{~kg} /$ day, respectively, without any gastrointestinal disorders. Godoi et al. (2009b) observed intake reduction in digestible neutral detergent fiber and digestible hemicelluloses of
1.1 and $0.9 \mathrm{~kg} /$ day, respectively, in horses fed diet with $19.5 \%$ soybean oil included.

There was no effect on the hematological parameters of rested horses fed diet with soybean oil, and only mean corpuscular hemoglobin $(\mathrm{MCV})$ differed $(\mathrm{P}<0.05)$ between horse groups, but it occurred at the beginning of the assay, before the diets were available (Table 4).

During the experimental period, the horses presented a hematological and biochemical profile with average values of packed cell volume, erythrocyte and hemoglobin lower and mean corpuscular volume higher than reference values. Total solid concentration and lymphocyte number, on the $82^{\circ}$ day of the experiment, presented higher than reference values. Other parameters were as cited by Smith (1993), Hodgson \& Rose (1994) and Robinson (1997).

Mean corpuscular hemoglobin concentration differed within the diets, with a higher value in horses fed hyperlipidemic diet, of $33.8 \%$, and a lower value in horses fed the control diet, of $32.4 \%$.

Lacerda et al. (2006) evaluated Brazilian saddle horses and observed $33.5 \%$ globular volume, $7.84 \%$ erythrocytes $\left(10^{6} / \mu \mathrm{L}\right)$ and $11.3 \mathrm{~g} / \mathrm{dL}$ hemoglobin and stated that breed and equestrian activity should be considered in a horse hematological evaluation. Ribeiro et al. (2008) evaluated Pantaneiro geldings in exercise activity and observed erythrocyte and packed cell volume values of $11.9 \mathrm{~g} / \mathrm{dL}$ and $32 \%$, respectively, and average corpuscular volume of $53.0 \mathrm{fL}$. The values cited are similar to those observed in the present study, indicating that native horses in Brazil present

Table 4 - Hematological and biochemical variables in horses at rest and fed diet with soybean oil, at the beginning, $60^{\text {th }}$ and $82^{\text {th }}$ days of the experiment

\begin{tabular}{|c|c|c|c|c|c|}
\hline \multirow[t]{2}{*}{ Analyte } & \multicolumn{3}{|c|}{ Experimental period } & \multirow[t]{2}{*}{$P($ Diet $)$} & \multirow[t]{2}{*}{ Reference values } \\
\hline & Beginning & $60^{\text {th }}$ day & $82^{\text {th }}$ day & & \\
\hline & \multicolumn{5}{|c|}{ Hematology } \\
\hline Hematocrit $(\%)$ & 32.0 & 30.8 & 34.3 & NS & $38-42^{1}$ \\
\hline Erytrocytes $\left(10^{6} / \mu \mathrm{L}\right)$ & 5.5 & 5.2 & 4.7 & NS & $7-11^{1}$ \\
\hline Hemoglobin $(\mathrm{g} / \mathrm{dL})$ & $10.6 \mathrm{Bab}$ & 9.9C.b & $12.5 \mathrm{Aa}$ & NS & $11-17^{1}$ \\
\hline Mean corpuscular volume (fL) & $58.2 \mathrm{Ba}$ & $59.9 \mathrm{Cb}$ & $74.5 \mathrm{Aa}$ & NS & $42-47^{1}$ \\
\hline Mean corpuscular hemoglobin concentration $(\%)$ & $33.0 \mathrm{Bab}$ & $32.0 \mathrm{ABb}$ & $36.5 \mathrm{Aa}$ & 0.018 & $31-39^{2}$ \\
\hline White blood cells $\left(10^{9} / \mathrm{L}\right)$ & 6.6 & 8.4 & 8.7 & NS & $6-11^{1}$ \\
\hline Neutrophils $\left(10^{9} / \mathrm{L}\right)$ & 3.4 & 4.7 & 3.0 & NS & $2.3-8.6^{3}$ \\
\hline Lymphocytes $\left(10^{9} / \mathrm{L}\right)$ & $2.6 \mathrm{Cab}$ & $4.2 \mathrm{Bb}$ & $5.8 \mathrm{Aa}$ & NS & $2.0-5.5^{1}$ \\
\hline Monocytes $\left(10^{9} / \mathrm{L}\right)$ & 0.4 & 0.7 & 0.5 & NS & $0.2-0.8^{1}$ \\
\hline \multirow[t]{2}{*}{ Eosinophils $\left(10^{9} / \mathrm{L}\right)$} & 0.2 & 0.2 & 0.3 & NS & $0-1.0^{1}$ \\
\hline & \multicolumn{5}{|c|}{ Blood biochemistry } \\
\hline Triglycerides (mg/dL) & 37.5 & 34.5 & 34.4 & NS & $40-44^{4}$ \\
\hline Cholesterol (mg/dL) & $102.2 \mathrm{Aa}$ & $81.2 \mathrm{Ba}$ & $94.6 \mathrm{Ca}$ & 0.007 & $75-150^{2}$ \\
\hline Urea nitrogen $(\mathrm{mg} / \mathrm{dL})$ & 27.3 & 34.3 & 47.3 & NS & $24-48^{1}$ \\
\hline Total solids $(\mathrm{g} / \mathrm{dL})$ & $6.5 \mathrm{Bab}$ & $6.2 \mathrm{Cb}$ & $8.0 \mathrm{Aa}$ & NS & $5.5-7.5^{1}$ \\
\hline Fibrinogen (mg/dL) & 336.4 & 333.3 & 395.5 & NS & $<400^{1}$ \\
\hline
\end{tabular}

Values in a line, followed by different uppercase letters are different $(\mathrm{P}<0.05)$, in function of the assay period within the control diet, by Friedman test.

Values in line, followed different lowercase letters are different, in function of the assay period within the diet, by Friedman test $(\mathrm{P}<0.05)$.

${ }^{1}$ Hodgson \& Rose (1994); ${ }^{2}$ Smith (1993); ${ }^{3}$ Robinson (1997); ${ }^{4}$ Kaneko (1997). 
a hematological profile with lower values for packed cell volume and hemoglobin and higher values for average corpuscular volume reported in the literature.

There was effect of time of the experiment $(\mathrm{P}>0.05)$ on hemoglobin concentration, average corpuscular volume, average corpuscular hemoglobin concentration, total solids and lymphocytes in blood samples collected from horses at rest , at the beginning and at the $60^{\text {th }}$ and $82^{\text {th }}$ day, in horses fed diet with soybean oil included and without it. Monocytes differed $(\mathrm{P}=0.018)$ only in horses fed the hyperlipidemic diet, with a higher value on the $60^{\text {th }}$ day of the experiment, of $0.7 \times 10^{9} / \mathrm{L}$.

The triglycerides, cholesterol and urea nitrogen concentrations were not altered by soybean oil inclusion in the diet $(\mathrm{P}>0.05)$. The cholesterol concentration differed $(\mathrm{P}=0.007)$ with a higher value at the beginning of the experiment, of $110.0 \mathrm{mg} / \mathrm{dL}$, in horses fed the control diet. Only the triglyceride values were below those reported by Kaneko (1997).

Unlike that observed in the present study, Zeyner et al. (2002) observed that in horses fed diet with $11.5 \%$ soybean oil included for 390 days, there was an increase in total solids and cholesterol concentration, with average values of 6.9 and $7.1 \mathrm{~g} / \mathrm{dL}$ and 90.5 and $106.3 \mathrm{mg} / \mathrm{dL}$, respectively, and a meaningful reduction in the urea nitrogen blood concentration in horses fed diet with soybean oil included, with average values of 35.8 and $32.1 \mathrm{mg} / \mathrm{dL}$, respectively, without alteration in the triglyceride concentrations, with an average value of $24.4 \mathrm{mg} / \mathrm{dL}$.

The three tests, heart rate, body temperature and lactate concentrations were influenced by exercise, with a higher value $(\mathrm{P}<0.05)$ immediately after the test (Table 5$)$.

Agreeing with results obtained in this assay, Meyers et al. (1989) and Marqueze et al. (2001) did not observe effect on heart rate before and 20 minutes after exercise in horses fed diet with or without soybean oil. However, Mattos et al. (2006) evaluated horses in exercise activity, trotting for 2 hours, and fed diets for 30 days with $0,3.1$ and $6.8 \%$ soybean oil included and verified that horses fed diet with more soybean oil included presented lower heart rate immediately after and 15 minutes after the exercise test.

There was effect of soybean oil inclusion on the $\gamma$-glutamyl transferase concentration on the $60^{\text {th }}$ day, and 120 minutes after the test $(\mathrm{P}=0.020)$, with higher value in horses fed the control diet, of $27.2 \mathrm{U} / \mathrm{L}$ and lower value in horses fed the hyperlipidemic diet, of $18.7 \mathrm{U} / \mathrm{L}$. On the $82^{\text {th }}$ day, the $\gamma$-glutamyltransferase blood concentration in horses at rest was influenced by the diets $(\mathrm{P}=0.014)$, with

Table 5 - Heart rate, body temperature and blood biochemical parameters of horses fed diet with soybean oil included and submitted to exercise tests at the beginning and on the $60^{\text {th }}$ and $82^{\text {th }}$ day

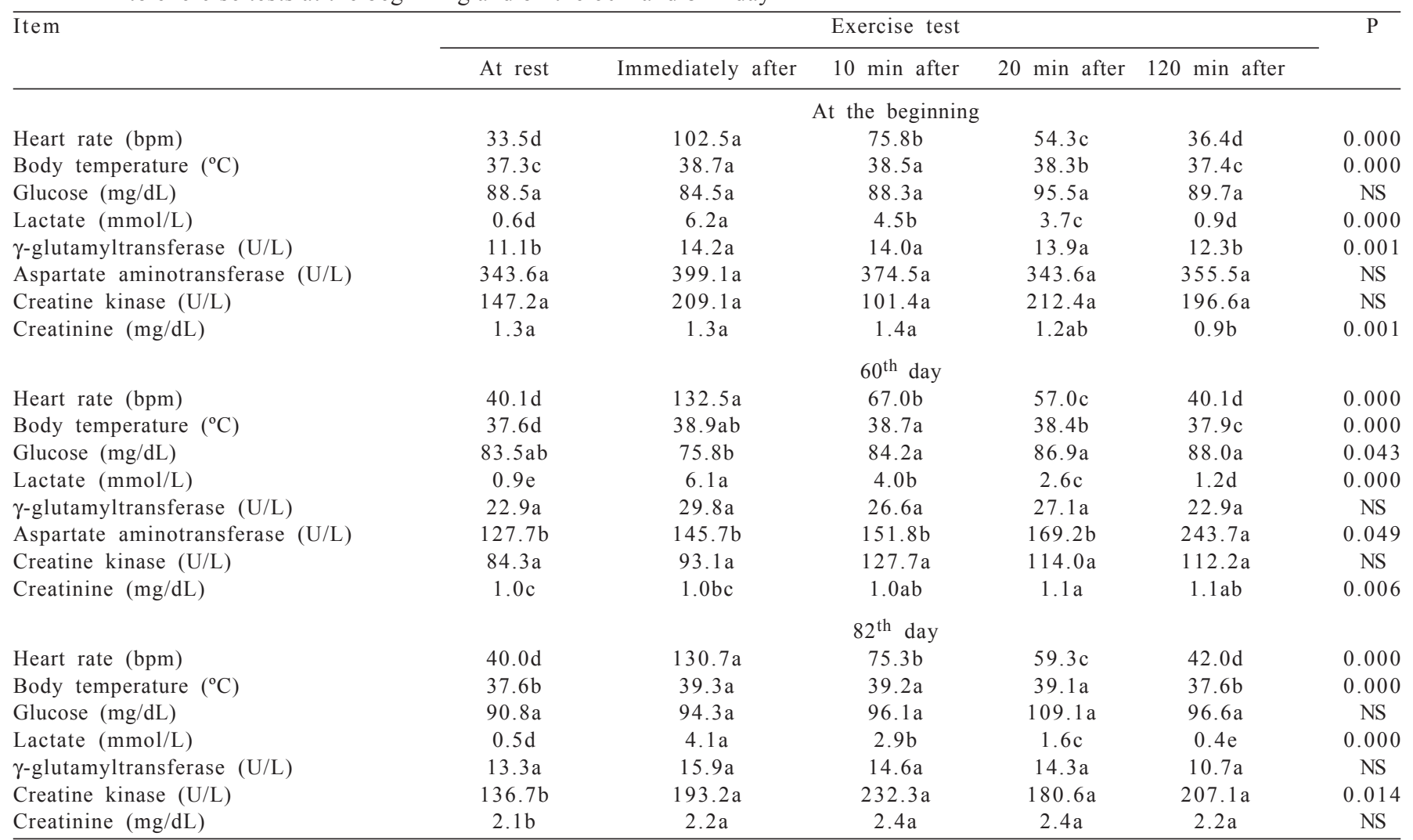

Values in a line followed different letters differ $(\mathrm{P}<0.05)$ in function of the collection time by Friedman test. 
higher value in horses fed the diet with soybean oil, of $17.0 \mathrm{U} / \mathrm{L}$ and lower value in horses fed the control diet, of $10.4 \mathrm{U} / \mathrm{L}$.

There was effect of soybean oil inclusion on the creatinine concentration only on the $82^{\text {th }}$ day of the experiment and at 120 minutes after the test $(\mathrm{P}=0.040)$, and a higher value was observed in horses fed with $10 \%$ soybean oil inclusion, of $2.6 \mathrm{mg} / \mathrm{dL}$ and lower values in horses fed the control diet, of $2.0 \mathrm{mg} / \mathrm{dL}$. Other evaluated parameters were not influenced by the diets.

There was effect of exercise on body temperature in all the physical effort tests, with a higher value immediately after exercise, varying from 38.7 to $39.3{ }^{\circ} \mathrm{C}$ (Table 6). Body temperature in horses was also influenced by weather variation, promoting higher metabolic distress in horses at the third exercise test, reducing heat loss from the horses, resulting in higher body temperature after exercise, of $39.9^{\circ} \mathrm{C}$. The body temperature of horses only decreased 120 minutes after the test had finished, while in other tests body temperature began to decrease 20 minutes after the tests. Mattos et al., (2006) verified that including soybean oil in the diet reduced body temperature at the end of 2 hours in horses at trot, with values of $39.2{ }^{\circ} \mathrm{C}$.

There was effect of physical effort and training on lactate concentration. Exercise influenced lactate levels, with higher values immediately after the test, and as time passed, values at rest returned. The return to basal values is an indicative of improvement in the horse performance according to training period. This was proved because there was an effect of training time with lower lactate concentrations at all the collection moments, observed on the $82^{\text {th }}$ day of the experiment. According to Lindner (2000), blood lactate is a variable that best correlates with exercise effort, and thus enables the evaluation of the horse conditioning.

Similar to this assay, Marqueze et al. (2001) did not observe meaningful difference in lactate concentration between horses fed diets with $(4.7 \%)$ or without soybean oil included, before and after exercise. However, Mattos et al. (2006) observed that in horses fed diets with 0,3.1 and 6.8\% soybean oil inclusion, the lactate concentrations differed $(\mathrm{P}<0.05)$ at the end of exercise effort, with higher values in horses fed diet with high soybean oil inclusion. This difference might be because of the type and duration of the exercise effort.

Gomide et al. (2006) evaluated lactate blood concentrations in eventing horses and observed that determining lactate concentration at the end of exercise and the horses capacity to reduce it allows to inference on exercise effort and training level. So it can be considered

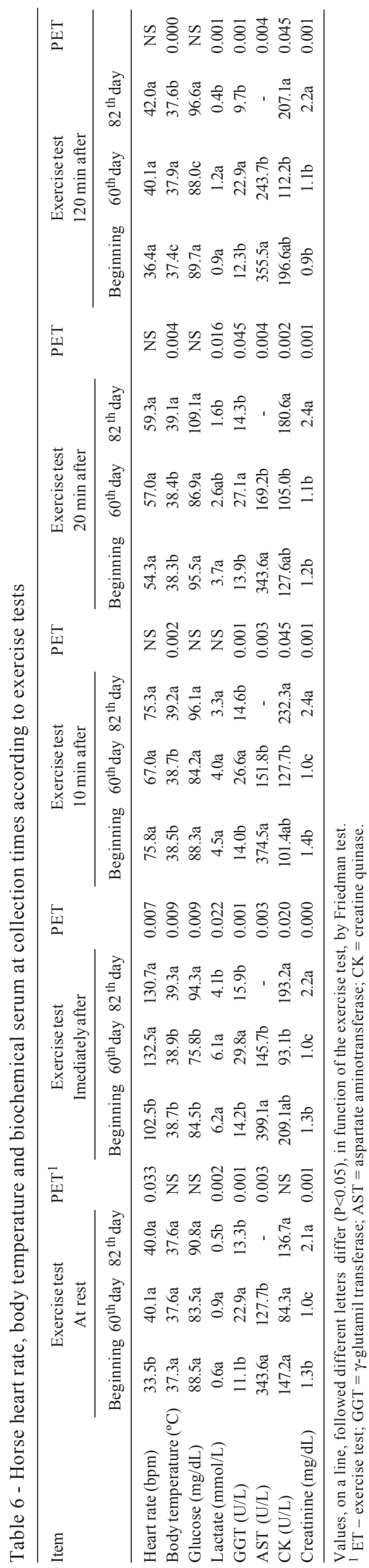

R. Bras. Zootec., v.39, n.2, p.335-343, 2010 
that the horses presented better conditioning at the third physical effort, on the $82^{\text {th }}$ day.

Plasmatic lactate concentrations were lower immediately after the test than values observed by Gomide et al. (2006) in horses at the resistance phase, after steeplechasing, of $6.95 \mathrm{mmol} / \mathrm{L}$, in an advanced eventing competition. The higher lactate concentration observed by these authors was probably because of the higher speed of $690 \mathrm{~m} / \mathrm{min}$ $(11.5 \mathrm{~m} / \mathrm{s})$, and duration of the competition to which the horses were submitted, relating to the physical effort test of this experiment, where the speed was $450 \mathrm{n} / \mathrm{min}(7.5 \mathrm{~m} / \mathrm{s})$, for 90 seconds.

Lactate is variable for each tested animal conditioning level, and regarding the physical training individuality, each animal adopted a determined speed. It is important to highlight that the steeplechase test was abandoned in eventing competitions, in the international scenario and in Brazil.

Only at the third test, on the $82^{\text {th }}$ day of the experiment, were the blood glucose levels in the horses influenced by exercise, differing $(\mathrm{P}=0.009)$ between blood collection time, however as normal values (Hodgson \& Rose, 1994). This fact can be explained by higher use of the lactate produced during exercise effort, as a precursor for glycogenesis after exercise, so glucose levels were higher after 10 minutes after the test was made. In other tests, blood glucose levels did not alter until 20 minutes after exercise.

Determinations of blood glucose and lactate levels are routinely used to evaluate energetic metabolism (Andrews, 1995). The glucose plasmatic concentration can be affected by several factors and it is the result of the balance between glucose offer and demand in the blood circulation that constitutes an important source of energy for muscular activity. There are controversies in the literature regarding blood glucose concentration in horses fed diets with oils and fats. Meyers et al. (1989) observed the glucose concentration decrease in horses fed diets with $10 \%$ of animal fat for 21 days and submitted to sub maximum exercise on a treadmill.

Agreeing with the present study, Marqueze et al. (2001) did not observe meaningful difference in glucose concentration among equines fed diet without or with $4.7 \%$ soybean oil for 21 days, before and after exercising. However, Zeyner et al. (2002) observed meaningful increase in glucose concentration in equines fed with soybean oil included in diet, at rest, when compared to animals fed diet without oil, with average values of 95.1 and $88.8 \mathrm{mg} / \mathrm{dL}$, respectively, after 390 days of diet intake.

Mattos et al. (2006) observed that glucose concentrations did not differ meaningfully before exercise among equines consuming diets with $0 ; 3.1$ and $6.8 \%$ soybean oil included, for 3 days, but observed meaningfully difference at the end of physical effort, with higher values in equines consuming hyperlipidemic diets.

Concentrations of $\gamma$-glutamyl transferase were influenced by the blood collection time only in the physical effort test at the beginning of the experiment $(\mathrm{P}=0.001)$, with normal values of 10 to $40 \mathrm{U} / \mathrm{L}$ (Hodgson \& Rose, 1994).

Aspartate aminotransferase concentrations presented effect of physical effort after 60 days of diet intake, with higher value at 120 minutes after the physical effort test, of $243.7 \mathrm{U} / \mathrm{L}$. In this test the value of this enzyme at rest was also verified and immediately after exercising, of 127.7 and 145.7 U/L, respectively, below normality (Hodgson \& Rose, 1994). The $\gamma$-glutamyl transferase and aspartate aminotransferase enzymes that are considered indicative of hepatic metabolism, kept values in normality, so that it can be inferred that the horses in this study did not present alterations in the hepatobiliary system.

Concentrations of creatine kinase affected the physical effort test after 82 days of diet intake, with a lower value at rest, of $136.7 \mathrm{U} / \mathrm{L}$. At the second test, on the $60^{\text {th }}$ day of the experiment, creatine kinase values were observed below normality for animals at rest and immediately after exercising, of 84.3 and $93.1 \mathrm{U} / \mathrm{L}$, respectively. Values of aspartate aminotransferase and creatine kinase below normality were probably because the horses were adapting to the exercise type and intensity.

According to values of aspartate aminotranferase and creatine kinase blood concentrations, the horses did not present muscle injuries until 120 minutes after the tests. However, the maximum concentration level of both enzymes could not be measured, certifying absence of muscle injury. According to Boffi (2006), creatin kinase and aspartate aminotransferase concentrations presented maximum level around 12 and 24 hours after muscle injury, respectively, and an increase of 10 to 900 times and 5 to 100 times over normal values for these enzymes, respectively, would be necessary to characterize muscle injury.

Based in quoted data it can be deduced that the training that the horses were submitted in this experiment was appropriate, because according to Frape (2004), the increase in blood concentrations of creatine kinase after exercise is related to increased muscular cell membrane permeability caused by hypoxia, which can be a result of improper training or excess physical effort.

Brandi et al. (2008) observed that in horses submitted to a $80 \mathrm{~km}$ long duration physical effort test on a treadmill, and consuming diets with 6 to $24 \%$ soybean oil included, presented decrease in aspartate aminotransferase and 
creatine kinase activity, showing direction to energetic metabolism to $\beta$-oxidation. These results differed from those reported in this experiment, probably because the intensity difference and duration of the exercises during physical effort.

Creatinine concentrations were influenced by exercise at the first and second physical effort tests. In the first test, there was difference at 120 minutes after exercising ( $\mathrm{P}=0.001)$, with lower value, of $0.9 \mathrm{mg} / \mathrm{dL}$ below normality, of 1.1 to $1.8 \mathrm{mg} / \mathrm{dL}$. In the second test, the creatinine concentration at rest, immediately after and 10 minutes after exercising were below normality.

In the third test, all the creatinine concentrations were over normality (Hodgson \& Rose, 1994). Creatinine increases during exercise, as a result of increased fosfocreatine turnover and consequently, creatinine increase in the plasma or serum, which does not necessarily indicate decrease in glomerular filtration. After exercises of maximum intensity, creatinine concentration stays high for 60 minutes (Hodgson \& Rose, 1994). However, the contrary was observed in this assay, where blood creatinine concentrations presented higher values at 10 and 20 minutes after the physical effort tests had finished.

According to the NRC (2007), many factors might be related to the contradictory results observed in literature, such as type and amount of the oils and fats used in equine diets, experiment duration, intensity variation and physical effort duration, in addition to the small number of horses used for treatment and difference in the physical conditioning of these animals. According to Hodgson \& Rose (1994), Boffi (2006), Mattos et al. (2006) and Brandi et al. (2008), the beneficial effect of diet intake with soybean oil on horse performance is more evident when they are submitted to low intensity and long duration exercise.

In high intensity exercise, carbohydrates are used as the main energy source, and fatty acids have little importance in these situations (Hodgson \& Rose, 1994). These authors reported an increase in free fatty acids in horse plasma at rest, of 47 to $1254 \mu \mathrm{mol} / \mathrm{L}$, which is an increase of $1,207 \mu \mathrm{mol} / \mathrm{L}$ after the $80 \mathrm{~km}$ resistance test. While for eventing horses, after the steeplechase phase, the presented increase was from 156 to $568 \mu \mathrm{mol} / \mathrm{L}$, an increase of $430 \mu \mathrm{mol} / \mathrm{L}$, indicating that the mobilization of fatty acids as energy source occurs more intensely in long duration exercises.

Soybean oil inclusion in diets enables the supply of the energetic demand with decrease in dry matter intake, avoiding gastrointestinal disturbances. These are beneficial factors that justify using oil sources in horse diets in any equestrian activity.

\section{Conclusions}

Training improves conditioning of horses by reducing plasmatic lactate and increasing plasmatic glucose at the last exercise test. Inclusion of soybean oil in the diet of eventing horses affected the plasmatic concentrations of $\gamma$-glutamyl transferase and creatinine through diet intake, while the other physiological, hematological and biochemical parameters evaluated were not altered. Soybean oil can be used in horse diets to supply energetic requirements and reduce dry matter intake that are desirable in equestrian activity.

\section{References}

ALMEIDA, F.Q.; PATITUCCI, L.T.; MIGON, E.X.F. et al. Plasma lactate evaluation in three days events horses. In: WORLD EQUINE VETERINARY ASSOCIATION CONGRESS, 8., 2003, Buenos Aires. Proceedings... Buenos Aires: WEVA, 2003.

ALMEIDA, F.Q.; VALADARES FILHO, S.C.; LEÃO, M.I. et al. Digestibilidade aparente pré-cecal, pós-ileal e total da proteína do milho e do farelo de soja em equinos. Revista Brasileira de Zootecnia, v.27, n.3, p.530-537, 1998.

ANDREWS, F.M.; GEISER, D.R.; WHITE, SUSAN L. et al. Haematological and biochemical changes in horses competing in a 3 star horse trial and 3-day-event. Equine Veterinary Journal, Suppl. n.20, p.57-63, 1995

BOFFI, F. Fisiología del ejercicio en equinos. 1.ed. Buenos Aires: Inter-Médica, 2006. 306p.

BRANDI, R.A.; FURTADO, C.E.; MARTINS, E.N. et al. Efeito de dietas com adição de óleo e do treinamento sobre a atividade muscular de equinos submetidos à prova de resistência. Acta Scientiarum Animal Science, v.30, n.3, p.307-315, 2008.

COLES, E.H. Patologia clínica veterinária. 3.ed. São Paulo: Manole, 1984. 566p.

EVANS, D.L. Training and fitness in athletic horses. 1.ed Sidney: RIRDC, 2000. 70p.

FÉDÉRATION EQUESTRE INTERNATIONALE - FEI. 2007. Disponível em: <http://www.horsesport.org/c/about/about.htm> Acesso: 15/9/2007.

FRAPE, D. Equine nutrition and feeding. 3.ed. Victoria: Blackwell Publ., 2004. 650p.

GODOI, F.N.; ALMEIDA, F.Q.; GUARIENTI, G.A. et al. Perfil hematológico e características das fezes de equinos consumindo dietas hiperlipidêmicas. Ciência Rural, v.39, n.9, p.110-120, 2009 a.

GODOI, F.N.; ALMEIDA, F.Q.; SALIBA, E.O.S. et al. Consumo, cinética digestiva e digestibilidade de nutrientes em equinos atletas alimentados com dietas contendo óleo de soja. Revista Brasileira de Zootecnia, v.38, n.10, p.1928-1937, 2009b.

GOMIDE, L.M.W.; MARTINS, C.B.; OROZCO, C.A.G. et al Concentrações sanguíneas de lactato em equinos durante a prova de fundo do Concurso Completo de Equitação. Ciência Rural, v.36, n.2, p.50-513, 2006.

HENNEKE, D.R.; POTTER, G.D.; KREIDER, J.L. et al. Relationship between condition score, physical measurements and body fat percentage in mares. Equine Veterinary Journal, v. 15, n.4, p.897-903, 1983. 
HODGSON, D.R.; ROSE, R.J. The athletic horse: principles and practice of equine sports medicine. 1.ed. Philadelphia: W.B. Saunders Co, 1994. 497p.

KANEKO, J.J. Clinical biochemistry of domestic animals. 5.ed. San Diego: Academic Press, 1997. 932p.

KRONFELD, D.S.; HOLLAND, J.L.; RICH, G.A. et al. Fat digestibility in Equus caballus follows increasing first-order kinetics. Journal of Animal Science, v.82, p.1773-1780, 2004.

LACERDA, L.; CAMPOS, R.; SPERB, M. et al. Hematologic and biochemical parameters in three high performance horse breeds from Southerm Brazil. Archives of Veterinary Science, v.11, n.2, p.40-44, 2006.

LINDNER, A. Use of blood biochemistry for positive performance diagnosis of sport horses in practice. Revue de Médicine Vétérinaire, v.151, p.611-618, 2000.

MARQUEZE, A.; KESSLER, A.M.; BERNARDI, M.L. Aumento do nível de óleo em dietas isoenergéticas para cavalos submetidos a exercício. Ciência Rural, v.31, n.3, p.491-496, 2001.

MATTOS, F.; ARAÚJO, K.V.; LEITE, G.G. et al. Uso de óleo na dieta de equinos submetidos ao exercício. Revista Brasileira de Zootecnia, v.35, n.4, p.1373-1380, 2006.
MEYERS, M.C.; POTTER, G.D.; EVANS, J.W. et al. Physiologic and metabolic response of exercising horses to added dietary fat. Journal of Equine Veterinary Science, v.9, p.218-223, 1989.

NATIONAL RESEARCH COUNCIL - NRC. Nutrient requirements of horses. 5.ed.rev. Washington, D.C.: National Academies Press, 1989. 100p.

NATIONAL RESEARCH COUNCIL - NRC. Nutrient requirements of horses. 6.ed.rev. Washington, D.C.: National Academies Press, 2007. $341 \mathrm{p}$.

RIBEIRO, C.R.; FAGLIARI, J.J.; GALERA, P.D. et al. Hematological profile of healthy Pantaneiro horses. Arquivo Brasileiro de Medicina Veterinária e Zootecnia, v.60, n.2, p.492-495, 2008.

ROBINSON, N.E. Current therapy in equine medicine. 4.ed Philadelphia: W.B Saunders Co., 1997. 800p.

SMITH, B.P. Tratado de medicina interna de grandes animais São Paulo: Manole, 1993. 900p.

ZEYNER, A.; BESSERT, J.; GROPP, J.M. Effect of feeding exercised horses on high-starch or high-fat diets for 390 days. Equine Veterinary Journal, v.34, p.50-57, 2002. 